\title{
IMPLEMENTASI PERMENDIKNAS NOMOR 28 TAHUN 2010 DI KABUPATEN SAMBAS
}

Oleh

Faisal $^{1}$

\begin{abstract}
Abstrak Permendiknas Nomor 28 Tahun 2010 mengatur tentang Penugasan Guru sebagai Kepala Sekolah/Madrasah, meliputi persyaratan umum dan persyaratan khusus, penyiapan calon, pengangkatan, masa tugas pengembangan keprofesian berkelanjutan, penilaian kinerja, mutasi dan pemberhentian kepala sekolah/madrasah. Tulisan ini bertujuan mengungkap proses pengangkatan kepala sekolah di Kabupaten Sambas dalam setting sekolah menengah pertama.
\end{abstract}

Kata Kunci: Rekrutmen, Seleksi dan Penempatan Kepala Sekolah

\section{Pendahuluan}

Terbitnya Permendiknas Nomor 28 Tahun 2010 tentang Penugasan Guru sebagai Kepala Sekolah/Madrasah ini tampaknya bisa dipandang sebagai momentum penting, yang memuat pesan serta membawa suatu amanat kepada penentu kebijakan di daerah, bahwa dalam kebijakan mengangkat dan menempatkan guru yang bertugas sebagai kepala sekolah harus proporsional dan profesional ( berimbang dan berdasarkan regulasi yang berlaku tidak berdasarkan "kedekatan")

Sayoginya sekolah dipimpin oleh orang yang benar-benar kompeten, baik dalam aspek kepribadian, sosial, manajerial, kewirausahaan, maupun supervisi (Permendiknas Nomor 13 Tahun 2007).

Dalam Permendiknas Nomor 13 Tahun 2007 tentang Standar Kepala Sekolah/Madrasah ditegaskan bahwa kompetensi kepribadian menuntut seorang kepala sekolah antara lain: berakhlak mulia, mengembangkan budaya dan tradisi akhlak mulia, dan menjadi teladan akhlak mulia bagi komunitas di sekolah; miliki integritas kepribadian sebagai pemimpin; memiliki keinginan yang kuat dalam pengembangan diri sebagai kepala sekolah; bersikap terbuka

\footnotetext{
${ }^{1}$ Faisal adalah kepala SMP Negeri 9 Teluk Keramat Kabupaten Sambas
} 
dalam melaksanakan tugas pokok dan fungsi; mengendalikan diri dalam menghadapi masalah dalam pekerjaan sebagai kepala sekolah dan memiliki bakat dan minat jabatan sebagai pemimpin pendidikan.

Kompetensi manajerial menuntut kepala sekolah antara lain harus mampu menyusun perencanaan sekolah, mampu mengembangkan organisasi sekolah, mampu memimpin sekolah secara optimal, mampu menciptakan budaya dan iklim sekolah yang kondusif, mampu mengelola guru dan staf, peserta didik, kurikulum, keuangan, sarana dan prasarana, mengelola sistem informasi sekolah dalam mendukung penyusunan program dan pengambilan keputusan; mampu memanfaatkan kemajuan teknologi informasi bagi peningkatan pembelajaran dan manajemen sekolah; melakukan monitoring, evaluasi, dan pelaporan pelaksanaan program kegiatan sekolah dengan prosedur yang tepat, serta merencanakan tindak lanjutnya.

Kompetensi kewirausahaan mengharuskan kepala sekolah bisa menciptakan inovasi yang berguna bagi pengembangan sekolah, bisa bekerja keras untuk mencapai keberhasilan sekolah, harus memiliki motivasi yang kuat untuk sukses dalam melaksanakan tugas, pantang menyerah dan selalu mencari solusi terbaik dalam menghadapi kendala yang dihadapi sekolah, serta memiliki naluri kewirausahaan.

Kompetensi supervisi mengharuskan seorang kepala sekolah mampu merencanakan program supervisi akademik dalam rangka peningkatan profesionalisme guru; melaksanakan supervisi akademik terhadap guru dengan menggunakan pendekatan dan teknik supervisi yang tepat; dan menindaklanjuti hasil supervisi akademik terhadap guru dalam rangka peningkatan profesionalisme guru.

Kompetensi sosial mengharuskan kepala sekolah mampu bekerja sama dengan pihak lain untuk kepentingan sekolah; berpartisipasi dalam kegiatan sosial kemasyarakatan; dan memiliki kepekaan sosial terhadap orang atau kelompok lain.

Untuk memperoleh kepala sekolah yang memenuhi unsur-unsur tersebut, maka pemerintah memandang perlu membuat suatu aturan dalam menangani masalah pengadaan pimpinan suatu sekolah. Sekarang ini, paling tidak ada dua regulasi pokok yang mengatur secara langsung tentang kepala sekolah, yaitu: Permendiknas Nomor 13 tahun 2007 tentang Standar kepala sekolah/madrasah, dan Permendiknas Nomor 28 tahun 2010 tentang penugasan guru sebagai kepala sekolah/madrasah. 
Undang-Undang Nomor 32 Tahun 2004 tentang Pemerintah Daerah berdampak juga pada kebijakan tentang pendidikan di daerah. Pemerintah Daerah diberi kewenangan untuk mengatur rumah tangganya sendiri, ini berarti bupati berwenang mengangkat pejabat-pejabat daerah di lingkungan kerjanya termasuk pengangkatan guru yang diberi tugas tambahan sebagai kepala sekolah. Secara teoritsnya, pengangkatan guru yang diberi tugas tambahan sebagai kepala sekolah harus berdasarkan karir, prestasi dan kebutuhan formasi yang ada serta regulasi yang berlaku .

Menurut penelitian yang dilakukan oleh Ridwan (2012.1) bahwa selama ini sering "terdengar" pengangkatan pejabat tidak terkecuali kepala sekolah berorientasi pada model "kedekatan" .Pengangkatan berdasarkan "model kedekatan" ini hasilnya banyak para pegawai merasa gelisah atau tidak tenang dalam bekerja apalagi pengangkatan pejabat tidak sesuai dengan kompetensi yang dimiliki berakibat rendahnya kinerja dan mutu pekerjaan. Hal ini juga merambah di dunia pendidikan yaitu merosotnya mutu pendidikan karena sekolah dipimpin oleh kepala sekolah yang tidak memiliki kompetensi.

Kenyataan lainnya menurut hasil penelitian Ridwan adalah bahwa selama ini pengangkatan kepala sekolah hanya didasarkan kepada pengalaman menjadi guru yang diukur dari segi waktu (lamanya menjadi guru). Kelengkapan administrasi sebagai syarat umum dan adanya kedekatan dari pejabat tertentu. Hal ini terasa kurang adil, mengingat untuk menjadi kepala sekolah profesional perlu dimulai dari pengangkatan yang profesional pula. Masa jabatan kepala sekolah seumur hidup harus ditinggalkan.

Permendiknas Nomor 28 tahun 2010 tentang penugasan guru sebagai kepala sekolah/madrasah, jelas-jelas memberikan amanat kepada pemerintah daerah bahwa, pemberian tugas tambahan kepada guru sebagai kepala sekolah hendaknya mengacu pada regulasi tersebut. Tuntutan profesionalisme untuk menjadi kepala sekolah, yang diatur dalam Permendiknas No: 162/U/2003 yang selanjutnya diperbaharui dengan Permendiknas nomor 28 tahun 2010 antara lain syarat-syarat, cara seleksi dan pengangkatan serta mengatur masa jabatan (periodesasi) kepala sekolah selama 4 tahun, sebenarnya merupakan salah satu strategi untuk meningkatkan kinerja kepala sekolah maupun calon kepala sekolah. 


\section{Rekrutmen}

Beberapa pengertian rekrutmen menurut para hali adalah sebagai berikut:

Samsudin (2006.81) rekrutmen adalah proses mendapatkan sejumlah calon tenaga kerja yang kualifaid untuk jabatan/pekerjaan tertentu dalam suatu organisasi.

Gomes (1995.105) mengatakan rekrutmen merupakan proses mencari, menemukan, dan menarik para pelamar untuk dipekerjakan dalam dan oleh suatu organisasi.

Triton (2009.63) mengatakan bahwa rekrutmen sebagai proses mencari, menemukan, dan menarik para pelamar untuk dipekerjakan dalam dan oleh organisasi sebagai langkah awal untuk mendapatkan calon karyawan yang setepat-tepatnya untuk menduduki suatu pekerjaan.

Jamaes.J.Jones \& Donald L.Walters (2008.126) rekrutmen adalah aktivitas-aktivitas yang terencana dalam menarik sejumlah individu yang berkualitasyang dibutuhkan untuk mengemban tugas-tugas yang ada di sebuah distrik operasional sekolah.

Triton (2009.66) mengatakan bahwa rekrutmen dalam pelaksanaannya tidak terlepas dari lingkungan internal dan ekternal organisasi. Lingkungan internal cukup menentukan dalam rekrutmen karena terkait political will dan motif-motif dalam organisasi, sedangkan ekternal yang berkaitan dengan rekrutmen adalah kondisi politik, sosial, ekonomi, bahkan hukum.

Sutrisno (2009.45) berpendapat bahwa proses rekrutmen sumber daya manusia tidak boleh diabaikan, hal ini disebabkan untuk menjaga supaya tidak terjadi ketidaksesuaian antara apa yang diinginkan dan apa yang didapat. Artinya organisasi tersebut tidak memperoleh karyawan atau pegawai yang tepat, dalam arti kata baik kualitas maupun kuantitasnya. Apa bila tidak terjadi sesuai dengan harapan organisasi atau institusi tersebut dapat dikatakan kemungkinan aktivitas kerja kurang efektif dan efisien, maka organisasi tersebut akan mengalami kegagalan.

Rekrutmen kepala sekolah dan kepala sekolah merupakan satu aktivitas manajemen yang mengupayakan didapatkannya seorang atau lebih calon pegawai yang betul-betul potensial untuk menduduki posisi tertentu di sebuah lembaga”. (Ibrahim Bafadal: 2003. 21) 
Dengan demikian, kemungkinannya adalah semakin baik proses rekrutmen kepala sekolah semakin besar pula kemungkinan diperoleh kepala sekolah yang baik sebagaimana harapan dan maksud rekrutmen.

Menurut Sutrisno (2009.46), sebuah proses rekrutmen dimulai dengan pencarian calon dan berakhir sampai lamaran mereka diterima. Tahap berikutnya setelah persiapan untuk melakukan rekrutmen selesai dikerjakan adalah mencari calon sebanyak jumlah yang diperlukan yang dianggap paling memenuhi syarat untuk mengisi lowongan.

Samsudin (2006.90-92) berpendapat bahwa sebuah proses rekrutmen biasanya terdiri dari beberapa langkah atau tahapan, yakni;

1. Mengidentifikasikan jabatan yang lowong.

2. Mencari informasi jabatan melalui analisis jabatan.

3. Menentukan calon yang tepat

4. Memilih metode-metode rekrutmen yang paling tepat.

5. Memanggil calon yang paling dianggap memenuhi persyaratan

6. Menyaring atau menyeleksi kandidat.

7. Membuat penawaran kerja

8. Mulai bekerja

Gomes (1995.105) mengatakan bahwa rekrutmen yang dilaksanakan dalam suatu organisasi karena adanya beberapa kemungkinan alasan yakni:

1. Berdirinya organisasi baru.

2. Adanya perluasan kegiatan organisasi.

3. Terciptanya pekerjaan-pekerjaan dan kegiatan-kegiatan baru.

4. Adanya pekerja yang pindah keorganisasi lain.

5. Adanya pekerja yang berhenti, baik dengan hormat maupun tidak hormat.

6. Adanya pekerja yang berhenti karena memasuki usia pensiun

7. Adanya pekerja yang meninggal dunia.

Ada sejumlah cara atau teknik yang dapat digunakan untuk mencari caloncalon untuk mengisi jabatan yang kosong dalam sebuah organisasi atau institusi. Oleh Sutrisno (2009.46-55) cara tersebut adalah sebagai berikut:

1. Mencari dari dalam.

Cara ini dapat dilakukan dengan :

a. Meminta bantuan karyawan lama.

b. Mencari dari arsip (bank data) pelamar. 
c. Mengumumkan secara terbuka di dalam perusahaan (organisasi /institusi)

2. Mencari dari luar.

Cara ini dapat dilakukan dengan :

a. Memasang iklan lowongan.

b. Memanfaatkan jasa Dinas Tenaga Kerja setempat

c. Menggunakan jasa konsultan dan Head Hunter.

d. Rekrutmen langsung di Kampus

e. Rekrutmen melalui organisasi propesi.

\section{Seleksi}

Sutrisno (2009.55) mengatakan bahwa pada tahap seleksi kita harus melaksanakan beberapa kegiatan yang tujuannya memilih calon di antara beberapa calon yang akan kita tawari pekerjaan atau jabatan yang memang harus diisi. Tujuannya dari tahap seleksi adalah mencari calon yang dianggap paling tepat untuk mengisi sebuah jabatan. Dengan kata lain, tujuan seleksi tidak hanya mencari orang yang baik, tetapi juga paling tepat bagi jabatan tersebut dalam tatanan dan lingkungan budaya suatu organisasi atau institusi.

Hasibuan (2006.47), berpendapat bahwa: "The selection process involved evaluating and closing among job candidates. Apllication form resumes, interview, and reference checks are commonly uses selection decress". (proses seleksi meliputi penilaian dan penetapan diantara caloncalon pengisi jabatan. Aplikasi dari penilaian, wawancara, dan pengecekan referensi adalah yang biasa digunakan dalam penetapan keputusan seleksi).

Samsudin (2005.92) mengatakan bahwa seleksi maksudnya pemilihan tenaga kerja yang sudah tersedia dan pada dasarnya bertujuan untuk mendapatkan tenaga kerja yang memenuhi syarat dan memiliki kualifikasi yang sesuai dengan deskripsi pekerjaan yang ada atau sesuai dengan kebutuhan organisasi.

Menurut Rivai \& Sagala (2009 : 158), bahwa proses seleksi merupakan rangkaian tahap-tahap khusus yang digunakan untuk memutuskan pelamar mana yang diterima, yang dimulai ketika pelamar melamar kerja dan diakhiri dengan keputusan penerimaan, sebagai hasil dari evaluasi para pelamar mengenai kesesuaian potensi mereka melalui penggunaan prosedurprosedur yang valid. 
Gomes (1995.117) menggandingkan seleksi dan penempatan. Beliau mengatakan bahwa proses seleksi dan penempatan merupakan salah satu fungsi terpenting dalam manajemen sumber daya manusia, karena tersedia/tidaknya pekerja dalam jumlah dan kualitas yang sesuai dengan kebutuhan organisasi, diterima / tidaknya pelamar yang telah lulus proses rekrutmen, tepat / tidaknya penempatan seorang pekerja pada posisi tertentu, sangat ditentukan oleh fungsi seleksi dan penempatan ini. Jika fungsi ini tidak dilaksanakan dengan baik maka dengan sendirinya akan berakibat fatal terhadap pencapaian tujuan-tujuan organisasi.

Triton (2009.72) mengatakan bahwa organisasi dapat dikatakan memiliki napas apabila memiliki kemampuan untuk mengambil keputusan apapun dan siap mengambil segala konsekuensi keputusannya tanpa melimpahkan atau membagi tanggung jawab atas pembuatan keputusan. Termasuk disini adalah keputusan hasil seleksi.

Wahyusumidjo (2005.354) berpendapat bahwa dalam proses seleksi itu terdiri dari empat tahap, yaitu : tahap awal, tahap pra seleksi, tahap seleksi dan tahap sesudah seleksi.

1. Tahap awal merupakan tahap dimana dilaksanakan suatu proses :

a. Identifikasi jabatan yang kosong.

b. Menentukan kriteria persyaratan calon untuk mengisi jabatan yang kosong.

c. Mengumumkan jabatan yang kosong kepada para calon.

d. Mengadakan perincian tugas dan tanggung jawab jabatan kepala sekolah yang kosong yang perlu diketahui calon.

e. menentukan persyaratan khusus yang diperlukan seperti kemampuan berbahasa, memiliki hasil pelatihan di bidang luar biasa tentang siswa.

f. mempersiapkan dokumen yang perlu diselesaikan oleh calon seperti :

- catatan tentang pendidikan dan pekerjaan,

- penampilan dan keberhasilan masa lampau,

- rekomendasi dan data-data yang mendukung.

2. Tahap Pra Seleksi

Menentukan dan mengatur bagaimana kebijaksanaan atau mekanisme seleksi dilaksanakan : 
a. Memilih dan menentukan siapa yang memikirkan cara dan prosedur untuk ditugaskan dalam hal-hal yang berkaitan dengan kegiatan tahap awal.

b. Ada jaminan bahwa kelompok staf atau satuan tugas yang akan ditugaskan benar-benar mampu melakukan penafsiran dan pemikiran data calon.

c. Bagaimana mengkaitkan atau mengintegrasikan kualifikasi calon dengan spesifikasi jabatan kepala sekolah yang akan diisi.

d. Menyaring calon yang berkualitas unggul.

e. Memilih calon terpilih untuk ditetapkan.

f. Mempersiapkan daftar calon yang memenuhi syarat.

\section{Tahap Seleksi}

Salah satu mata rantai kegiatan seleksi adalah pencocokan atau pengintegrasian antara spesifikasi jabatan kepala sekolah yang harus diisi dengan kualifikasi calon. Dalam tahap seleksi ini akhirnya harus diambil keputusan untuk memilih calon terbaik.

\section{Tahap Setelah Seleksi}

Dalam proses ini ada beberapa hal yang harus diperhatikan yaitu :

a. Calon-calon yang tidak memenuhi persyaratan atau yang tidak diterima

b. Calon-calon yang diterima untuk diangkat menjadi kepala sekolah

c. Dibuat daftar nominasi calon, lengkap dengan dokumen serta proses dikeluarkannya surat keputusan pengangkatan dan penempatan.

Proses seleksi menurut para ahli dianggap sebagai proses penyewaan tenaga ahli (the hiring proces). Mereka menganggap hiring dan selection merupakan konsep ketenagakerjaan yang "interchangeable" (dapat saling ditukar istilahnya). Dalam proses seleksi, akan terjadi antara "menyewa" (bagi pelamar tenaga kerja yang lolos seleksi) dengan "tidak jadi memyewa" (bagi pelamar yang tidak memenuhi syarat), maka mereka lebi menyukai "proses seleksi" dari pada "proses penyewaan" tenaga kerja (Samsudin:2009.95)

Selanjutnya Samsudin (2009.95-96) mengatakan bahwa ada dua pendekatan dalam proses seleksi yakni :

1. Pendekatan Succesive Hurdles 
Untuk berhasil pelamar diterima dalam suatu organisasi, mereka harus lulus dari berbagai persyaratan yang telah ditentukan secara bertahap, mulai dari mengisi belangko, tes, wawancara dan segala macam tes dan harus lulus secara berurutan.

\section{Pendekatan Conpensantory.}

Seorang pelamar dapat diterima berdasarkan hasil keseluruhan hasil tes yang diikutinya. Kekurangan satu sisi diharapkan dapat ditutupi oleh kelebihan disisi lain.

\section{Penempatan.}

Rivai dan Sagala (2011.198) berpendapat bahwa penempatan adalah penugasan atau penugasan kembali seorang karyawan kepada pekerjaan barunya. Keputusan penempatan lebih banyak dibuat oleh manajer lini, biasanya supervisor seorang karyawan dengan berkonsultasi menenentukan penempatan karyawan (pegawai) dimasa datang.

Yuniarsih dan Suwatno (2009.115) mengemukakan bahwa penempatan (placement) berkaitan dengan pencocokan seseorang dengan jabatan yang akan dipegangnya. Kemudian Yuniarsih dan Suwatno berkesimpulan bahwa penempatan pegawai tidak sekedar menempatkan saja, melainkan harus mencocokkan dan membandingkan kualifikasi yang dimiliki pegawai dengan kebutuhan dan persyaaratan dari suatu jabatan atau pekerjaan, sehingga the right man on the right job tercapai.

Menurut Rivai dan Sagala (2011.198) dalam alur penempatan terdapat tiga jenis alur penting dari penempatan, yaitu promosi, transfer dan demosi. Setiap keputusan harus diiringi dengan orientasi dan tindak lanjut, apa pun penyebabnya seperti perampingan, merger, akuisisi atau perubahan internal organisasi.

Dalam kaitan ini Yuniarsih dan Suwatno (2009.116) mengemukakan bahwa penempatan pegawai dilakukan setelah pegawai bersangkutan lulus seleksi. Hal tersebut tidak saja berlaku bagi pegawai baru, tapi juga bagi penempatan pegawai lama, baik promosi, alih tugas dan demosi. Promosi terjadi apabila seorang pegawai atau karyawan dipindahkan dari satu jabatan atau pekerjaan ke jabatan atau pekerjaan yang lebih tinggi baik pangkat, pembayaran, tanggungjawab maupun levelnya. Tranfer atau alih tugas terjadi kalau seorang karyawan atau pegawai dipindahkan dari satu bidang tugas ke 
bidang tugas lainnya yang tingkatannya hampir sama baik gaji, tanggungjawab mau pun tingkat strukturalnya. Demosi terjadi kalau seorang karyawan atau pegawai dipindahkan dari satu posisi ke posisi lainnya yang tingkatannya lebih rendah baik gaji, tanggungjawab mau pun tingkat strukturalnya.

Selanjutnya Yuniarsih dan Suwatno (2009.117) mengutip beberapa pendapat para ahli terkait faktor-faktor yang perlu dipertimbangkan dalam penempatan pegawai adalah sebagai berikut:

Schuler dan Jackson bahwa dalam melakukan penempatan pegawai hendaklah mempertimbangkan faktor-faktor keterampilan, kemampuan, preferensi dan kepribadian pegawai.

Wahyudi mengemukakan bahwa dalam melakukan penempatan pegawai hendaklah mempertimbangkan faktor-faktor ; pendidikan, pengetahuan kerja, keterampilan kerja ( meliputi keterampilan mental, fisik dan sosial) dan pengalaman kerja.

Sedangkan Satrohadiwiryo mengemukakan faktor yang harus dipertimbangkan dalam menempatkan pegawai yakni; prestasi akademis, pengalaman, kesehatan fisik dan mental, status perkawinan dan usia.

\section{Proses Rekrutmen Kepala Sekolah menurut Permendiknas No 28 Tahun 2010}

Permendiknas No. 28 Tahun 2010 tentang Penugasan Guru Sebagai Kepala Sekolah/Madrasah, terdiri dari 10 Bab dan 20 Pasal, dengan sistematika sebagai berikut:

a. Bab I Ketentuan Umum

b. Bab II Syarat-Syarat Guru yang Diberi Tugas Tambahan Sebagai Kepala Sekolah/Madrasah

c. Bab III Penyiapan Calon Kepala Sekolah/Madrasah

d. Bab IV Proses Pengangkatan Kepala Sekolah/Madrasah

e. Bab V Masa Tugas

f. Bab VI Pengembangan Keprofesian Berkelanjutan

g. Bab VII Penilaian Kinerja Kepala Sekolah/Madrasah

h. Bab VIII Mutasi dan Pemberhentian Tugas Guru sebagai Kepala Sekolah/Madrasah

i. Bab IX Ketentuan Peralihan

j. Bab X Ketentuan Penutup 
Regulasi tersebut secara tidak langsung mengambil alih kewenangan pemerintah daerah oleh pemerintah pusat (Kemdikbud) dalam hal penetapan penugasan tambahan bagi guru sebagai kepala sekolah mulai jenjang TK/RA, SD/MI, SMP/MTs, SMA/MA/SMK.

Dengan demikian, jabatan kepala sekolah berdasarkan Permendiknas No.20 tahun 2010 adalah jabatan pemimpin suatu sekolah yang tidak dapat diisi oleh sembarang guru. Artinya, seorang guru yang akan diberi tugas tambahan sebagai kepala sekolah, harus melalui beberapa prosedur. Melaui prosedur serta persyaratan-persyaratan tertentu seperti; latar belakang pendidikan, pengalaman, usia, pangkat, integritas, dan harus lulus seleksi sehingga mendapatkan lisensi sebagai kepala sekolah, diharapkan terjaring seorang kepala sekolah yang betul-betul memiliki kompetensi sebagai seorang pemimpin institusi pendidikan yang baik dan bermutu.

Dengan terbitnya Permendiknas No 28 Tahun 2010, sayogianya juga didukung oleh adanya kebijakan Pemerintah Daerah, khususnya Pemerintah Kabupaten Sambas dalam bentuk peraturan daerah untuk mendasari pelaksanaan proses rekrutmen calon kepala sekolah di wilayah pemerintahan kabupaten Sambas.

Namun kenyataannya upaya menjaring calon kepala sekolah di Kabupaten Sambas oleh Tim Rekrutmen dan Seleksi yang telah dibentuk oleh Dinas Pendidikan Kabupaten Sambas, tidak sepenuhnya pelaksanaan sesuai dengan Permendiknas No 28 Tahun 2010. Hal ini dibuktikan dengan ditunjuknya guru untuk mengelola beberapa unit sekolah baru antara lain SMPN 7 Sambas dan SMPN 3 Selakau Timur. Guru yang ditunjuk sebagai ketua pengelola unit sekolah baru (USB) tersebut selanjutnya kemungkinan besar akan diberi tugas tambahan sebagai kepala sekolah pada sekolah yang bersangkutan.

Alasan keterdesakan dan kondisi daerah di satu sisi dan pelaksanaan Permendiknas No 28 Tahun 2010 yang memerlukan rentang waktu relatif panjang untuk penetapan seorang guru yang diberi tugas tambahan sebagai kepala sekolah disisi lainnya, maka keputusan alternatif menjadi pilihan. Tentu penunjukan guru sebagai ketua pengelola unit sekolah baru (USB) tersebut di dasarkan atas berbagai pertimbangan dan saran dari pihak terkait (pengawas, kepala sekolah, guru dan pihak dinas pendidikan). 
Penelitian Ridwan (2012.126) menyimpulkan bahwa faktor-faktor yang menghambat implementasi Permendiknas No. 28 tahun 2010 di Kabupaten Sambas antara lain yakni: terutama hambatan yang berhubungan dengan dana, kurangnya koordinasi antara Dinas Pendidikan dan Badan Kepegawaian Daerah Kabupaten Sambas sehingga menyebabkan belum dianggarkannya dana untuk program Pendidikan dan latihan calon kepala sekolah, belum adanya sosialisasi dari Kementrian Pendidikan dan Kebudayaan tentang pemberlakuan Permendiknas Nomor 28 Tahun 2010.

\section{Penutup.}

Pelaksanaan Permendiknas No. 28 tahun 2010 tentang penugasan guru sebagai kepala sekolah/madrasah di Kabupaten Sambas belum dilaksanakan sepenuhnya oleh dinas pendidikan dalam merekrutmen calon kepala sekolah khususnya tingkat SMP. Ketentuan yang belum dapat dilaksanakan oleh dinas pendidikan Kabupaten Sambas yakni melaksanakan pelatihan bagi calon kepala sekolah di lembaga terakreditasi yang telah lulus seleksi untuk memiliki sertifikat kepala sekolah/madrasah.

Rekomendasi dari penulis, agar pemerintah daerah dan lembaga legislatif di daerah Kabupaten Sambas bersama-sama berbuat sesuai dengan tupoksinya masing-masing yang sinergis untuk memajukan dunia pendidikan di kabupaten Sambas, dimulai dari membuat suatu regualsi yang memihak kepada implementasi Permendiknas No. 28 tahun 2010. Karena di yakini bahwa dengan implementasi secara utuh Permendiknas No. 28 tahun 2010 diharapkan terjaring seorang kepala sekolah yang bermutu sesuai dengan perkembangan jaman.

\section{Pustaka}

Bafadal, I. 2003. Peningkatan Profesionalisme Kepala sekolah Sekolah Dasar, Jakarta: Bumi Aksara.

Gomes. C.F. 1995 Manajemen Sumber Daya Manusia, Yogyakarta : Andi Offset.

Hasibuan, H.M .2006. Manajemen Sumber Daya Manusia, ed.revisi. Jakarta: PT. Bumi Aksara.

Jamaes.J.Jones \& Donald L.Walters.2008.Human Resource Management In Education, Yogyakarta : Q-Media. 
Peraturan Menteri Pendidikan Nasional Nomor 13 Tahun 2007 tentang Standar Kepala Sekolah/Madrasah

Permendiknas Nomor 28 tahun 2010 tentang penugasan guru sebagai kepala sekolah/madrasah.

Ridwan. 2012. Rekrutmen, Seleksi dan Penempatan Kepala Sekolah Menengah Atas Negeri Di Kabupaten Sambas ( Studi Atas Implementasi Permendiknas Nomor 28 tahun 2010) Tesis. Tidak diterbitkan. Pontianak. PPS AP FKIP UNTAN.

Samsudin.S. 2006. Manajemen Sumber Daya Manusia. Bandung. Pustaka Setia.

Sutrisno. Edy .2009. Manajemen Sumber Daya Manusia. Jakarta. Kencana.

Tjutju Yuniarsih dan Suwatno. 2009. Manajemen Sumber Daya Manusia.Teori, Aplikasi dan Isu penelitian.Bandung. Alfabeta.

Triton PB. 2009. Mengelola Sumber daya Manusia. Kinerja, Motivasi kepuasan kerja dan Produktivitas.Yogjakarta. Oryza.

Undang-Undang Nomor 32 Tahun 2004 tentang Pemerintah Daerah.

Veithzal Rivai \& Ella Jauvani Sagala. 2009. Manajemen Sumber Daya Manusia untuk Perusahaan: Dari Teori ke Praktik. Jakarta. PT.Rajagrafindo Persada.

Wahjosumidjo. 2005. Kepemimpinan kepala sekolah. Jakarta : Ghalia Indonesia 